\section{Preliminary Corrosion Testing of Steel Rebar Samples in 3.5\% NaCl Solution with and without a Green Inhibitor}

Shaymaa Abbas ABDULSADA PhD student in Faculty of Materials Science and Engineering, University of Miskolc, Hungary. Lecturer at Faculty of Engineering, University of Kufa, Iraq Research Interests: Corrosion Engineering Metallurgy Engineering, Heat Treatment of Metals, Casting of Metals.

ShaYmaA AbBas ABDULSADA - Faculty of Materials Science and Engineering, University of Miskolc= qkosha86@uni-miskolc.hu

TAMÁs I. TÖRÖK - Faculty of Materials Science and Engineering, University of Miskolc. fektt@uni-miskolc.hu

EvA FAZAKAS - Department of Surface Technology,

Bay Zoltán Nonprofit Ltd. for Applied Research - eva.fazakas@bayzoltan.hu

Érkezett: 2017. 12. 30. - Received: 30. 12. 2017. - https://doi.org/10.14382/epitoanyag-jsbcm.2018.10

\begin{abstract}
The applicability of a new organic inhibitor extracted from a cheap organic waste of orange peel (so-called "green" inhibitor) was studied in a laboratory system where the steel rebar samples obtained from a steel mill operating in Hungary were investigated in several sets of experiments to reveal their major corrosion properties in aqueous solutions containing sodium chloride salt. The initial corrosion rates were determined by a standard electrochemical polarisation technique on active (scale and rust free) steel specimen while being immersed in $3.5 \% \mathrm{NaCl}$ aqueous solutions containing the methanol extract of the chosen green inhibitor in a preliminary test run of 24 hours. Due to the inhibitor's active groups identified by FTIR spectroscopy, this new green inhibitor (with concentrations tested at 1 and 3\%) showed promising surface adsorptive and corrosion mitigating effects examined also by scanning electron microscopy (SEM) combined with EDS surface analysis. These SEM-EDS surface analyses were performed on the given rebar samples after an immersion (i.e. corroding) period of one month.

Keywords:, Steel reinforcement, orange peels, corrosion properties, SEM EDS analysis.
\end{abstract}

Tamás I. TÖRÖK Professor of Chemical Metallurgy and Surface Technologies at University of Miskolc, Hungary. First Secretary of HUNKOR, the Hungarian Corrosion Society, and former President of ASM International Hungary Chapter. Recent Research Interests: Corrosion Phenomena, Protective Coatings, Metals Surface Treatments and Surface Engineering.

Éva FAZAKAS Head of Department in Bay Zoltán Nonprofit Ltd. for Applied Research, Budapest. As the head of the department I am in charge of arranging and realizing the professional development works of the department, as well as organizing and co-ordinating the industria and $R \& D$ projects related to their fields of competence.

Research interest: Corrosion Engineering Material Science, Structural analysis of metals, Heat treatment of Metals, Casting and mechanical alloying of metals.

\section{Introduction}

As it is stated in many relevant publications, the corrosion of steel reinforcement is a major problem influencing the longterm performance of reinforced concrete structures. It typically occurs due to onslaught of aggressive agents such as chloride ions from marine environment, deicing salt or chloride contaminated aggregate. In the subsistence of chloride, the protective passive stratum of steel is locally destroyed and the unprotected steel areas starts dissolve. The formation of corroding products (rust) involves a substantial volume increase, i.e. the volume of corrosion products is greater than that of original steel bar. Therefore expansive stresses are induced around corroded steel bars causing possible cracking, spalling of concrete cover and loss of bond between steel/ concrete, and thus reducing the serviceability of concrete structures [1-6].

Cracking of the concrete cover is a critical limit state and this is often modelled as a two-stage process that consists of a) an initiation phase, defined as the time taken for corrosion to commence, and b) propagation phase (Fig. 1), where the accumulation of corrosion products induces expansive stresses and damage. Until recently, most research has focused on the time up to corrosion initiation, while the propagation phase leading to failure remains poorly understood as it is stated in a recent report of Wong et al. [7].

Anyhow, as a preventive measure against steel rebar corrosion, it is highly recommended by many corrosion experts [e.g. 8-11] studying the mechanism of the reinforcing steel corrosion in concretes, that inhibitors added to the fresh concrete mixtures can effectively defer the initiation phase of corrosion as well as decrease its rate during the propagation phase.

As it is well known, the corrosion inhibitors are chemical substances that when added in small amount to concrete mix decrease or slow down corrosion rate by changing the surface condition of the reinforced steel [12]. Most of the corrosion inhibitors are classified as organic and inorganic ones according to their chemical nature as well as anodic, cathodic or mixed inhibitors according to the electrochemical reaction on the steel surface with its environment [13]. Considering their material sources and varieties, recently the popularity and use of synthetic chemical compounds as corrosion inhibitors is diminishing due to the strict environmental regulations and toxic effects of many synthetic compounds on human and animal life. Consequently, there exists the need to develop a new class of corrosion inhibitors with low toxicity, eco-friendliness and good efficiency. Throughout the ages, plants have been used by human beings for their basic needs such as production of food-stuffs, shelters, clothing, fertilizers, flavors and fragrances, medicines and last but not least, as corrosion inhibitors. The use of natural products as corrosion inhibitors can be traced back to the 1930's when plant extracts of Chelidonium majus (Celandine) and other plants were used for the first time in $\mathrm{H}_{2} \mathrm{SO}_{4}$ pickling baths $[14,15]$.

Extracts of plants materials contain a wide variety of organic compounds [16]. The natural constituents of these extracts contain $\mathrm{N}, \mathrm{O}$, and $\mathrm{S}$ containing heterocyclic macromolecules, which when reaching the steel surface by diffusion and got adsorbed at the steel concrete interface by secondary molecular interaction with the metal and metal oxide they 

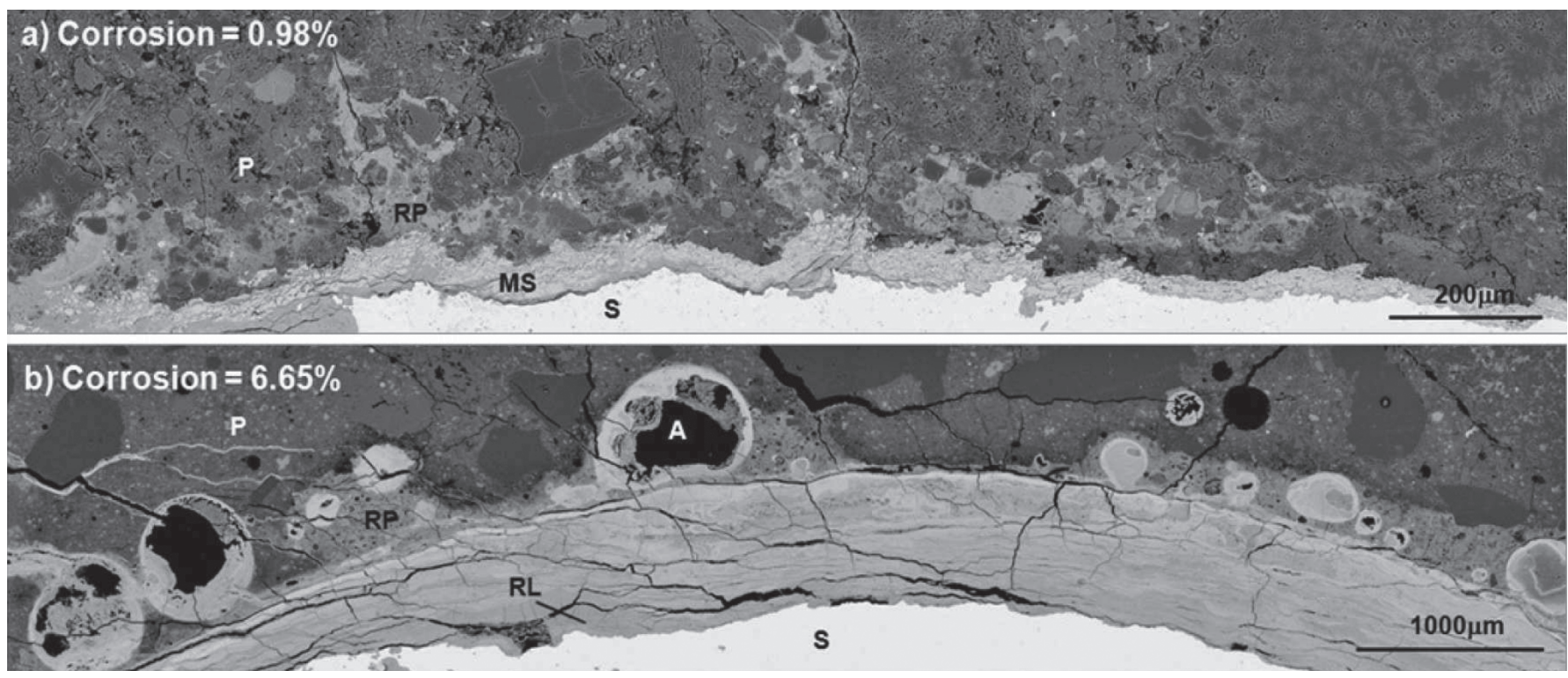

Fig. 1. BSE images of samples with different degrees of corrosion, showing rust accumulating at the steel-concrete interface and migrating into the cement paste, cracks and air voids (S: Steel, MS: Millscale, RL: Rust layer, RP: Rust-filled paste, P: Unaffected Paste) [7]

1. ábra Elektronmikroszkópos (BSE) felvételek különbözö mértékü korróziós károsodásokról vasbetonban: az acélbetét és a beton határfelületén keletkezett és felszaporodott rozsda bepréselödött a cemetpépbe, a repedésekbe és a légüregekbe (Jelölések az ábrán: S: acél, $M S:$ reve, RL: rozsdaréteg, RP: rozsdával penetrálódott cementkö, P: nem károsodott cementkö (megkötött cementpép). [7]

can form protective layers to repeal water molecules and inhibit ingression of destructive species like $\mathrm{Cl}^{-}, \mathrm{SO}_{4}{ }^{2-}$, and $\mathrm{CO}_{2}$ which are responsible for the depassivation of steel during the initiation phase of corrosion [17].

Getting motivated by the above described new tendencies and continued need of further research in this field, the main purpose of this study was to perform experimental laboratory tests to reveal the major corrosion related properties of steel rebar samples immersed in sodium chloride solution in contact with air. This approach is well justified as such or similar situations might also arise during the real and long service life of steel reinforced concrete structures and must be addressed in order to mitigate the risk of their degradation in such harsh (e.g. close to the see) environmental conditions. And, towards that aim, testing the potential of a new green inhibitor can be an important step forward in this respect.

\section{Materials and methods}

The steel rebar samples were obtained from a secondary steel making factory (Ózd Steelworks Ltd.), which produces different hot rolled rod and wire products. The hot rolled and ribbed reinforcing steel bar samples with diameter of about 8 $\mathrm{mm}$ were cut to $10 \mathrm{~cm}$ long pieces. The steel quality was in compliance with the standard EN 10080 [18] and contained about 0.2 wt.\% C, somewhat over $1 \% \mathrm{Mn}$, and about $0.3 \% \mathrm{Si}$ as the main alloying elements. The as-received rod samples surface was covered with a thin layer of mill scale (iron oxide) which for some further corrosion testing experimental sets was removed by standard acid pickling in $\mathrm{HCl}$ solution.

In order to detect the active compounds of the powder of the ground dry orange peel, their FTIR spectra were also recorded. This test provides information about the chemical bonding or molecular structure of materials; determines the chemical types of components in the mixture, and whether they are organic or inorganic. The BRUKER type FTIR spectroscope (IRAffinity-1S) was equipped with a diamond crystal, and always a clean, empty diamond crystal was used for the collection of background spectrum.

The inhibitor tested in these experiments was a methanol extract of fine ground dry orange peel. The Soxhlet-extraction was made for 6 hours, then the methanol was evaporated under reduced pressure $(60 \mathrm{mbar})$ at $40^{\circ} \mathrm{C}$ and the extract was dispersed/dissolved in distilled water. This aqueous suspension of the orange peel extract was then used as an inhibitor stock solution/suspension and was added in different percentages to the corrosion test electrolyte solutions of $\mathrm{NaCl}$.

To estimate the initial corrosion rates, the properly prepared steel samples were put in the $\mathrm{NaCl}$ test solutions both without and with added orange peel extract as the inhibitor. During the polarization measurements the (steady-state open circuit) corrosion potentials $(E / \mathrm{V})$ were recorded referenced to a saturated calomel electrode (SCE), then the electrode potential was scanned with a constant rate of $10 \mathrm{mV} / \mathrm{min}$ „down" to more negative (i.e. so-called cathodic) polarisation potentials of $-2.5 \mathrm{~V}_{\mathrm{SCE}}$. Then the potential was reversed and scanned with the same rate through the $E / \mathrm{V}$ corrosion potential up to about $+2.0 \mathrm{~V}_{\mathrm{SCE}}$ more positive value than that of the corrosion potential. In this way a total potential range of almost $4.5 \mathrm{~V}$ were scanned. This procedure was then repeated in the same manner after longer periods of immersion times of $1 \mathrm{~h}, 3 \mathrm{~h}, 5 \mathrm{~h}$, $7 \mathrm{~h}$, and 24 hours.

In the other sets of experiments both the initial surface state (i.e. mill-scale covered / as-received one) and the corroded surface conditions were characterized by scanning electron microscopy (SEM) coupled with energy-dispersive X-ray spectroscopic micro-analyser (EDS). Before the SEM-EDS testing the samples were left corrode for one month in $\mathrm{NaCl}$ solutions in contact with air both without and with green inhibitors of only $1 \%$ and $3 \%$, respectively. 


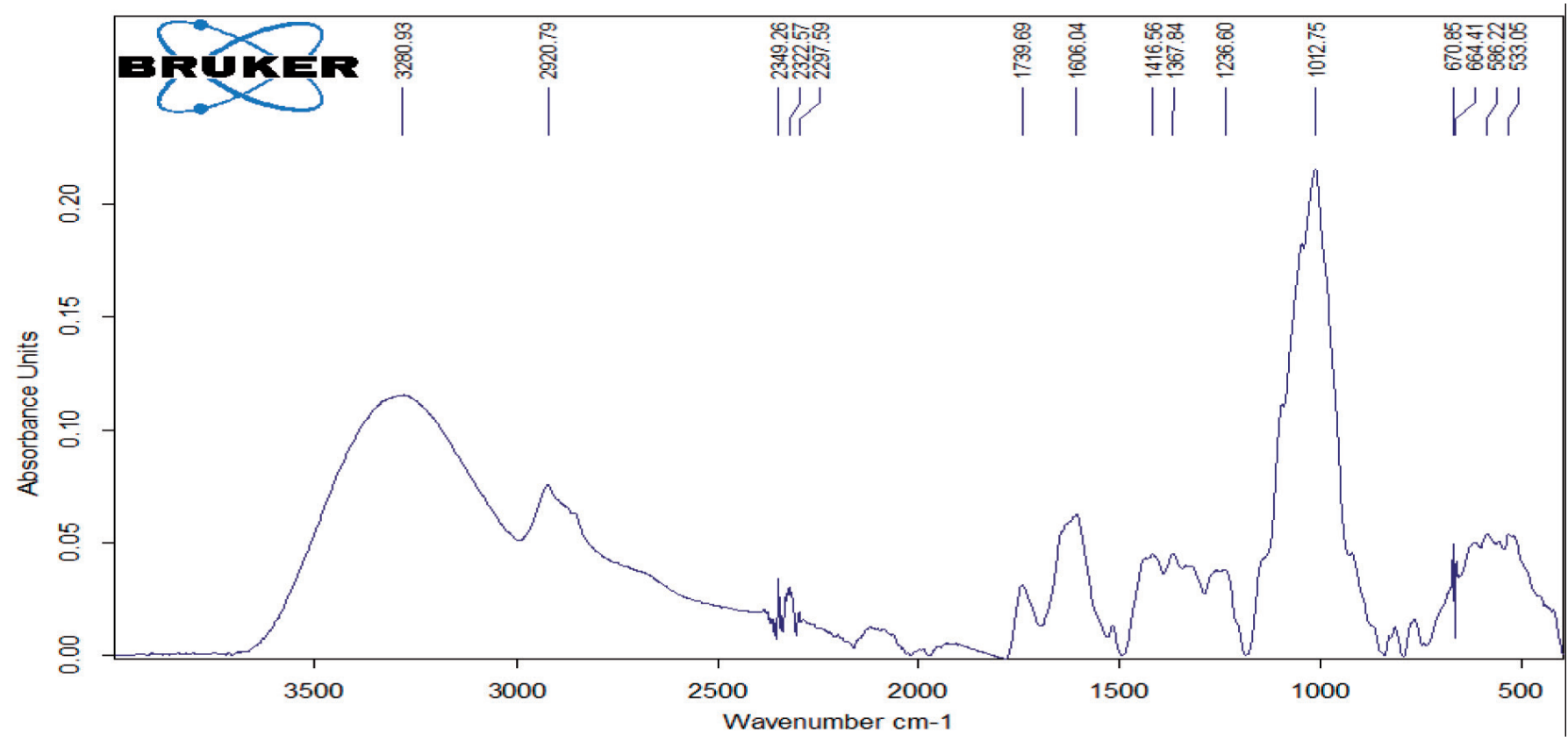

Fig. 2. Fourier transform infrared spectrum (FTIR) of the dry orange peel powder depicting its IR absorbance peaks in the function of wavenumber with the most significant values indicated above the peaks

2. ábra Szárított narancshéj por Fourier-transzformációs infravörös (FTIR) spektruma; a legjellemzőbb abszorpciós csúcsokhoz rendelhető hullámszám értékekkel is jellemezve

\section{Results and discussion}

\subsection{Analysis of the Powdered Orange Peel}

The dry and ground orange peel sample was first studied by recording its FTIR spectrum (Fig. 2) in order to detect its most probable IR active functional groups. In accordance with the relevant literature [19] our chosen natural organic material should also contain chemical constituents like organic fats, pectins, lignin, reducing and non-reducing sugars all of which have many active functional groups (carboxyl, hydroxyl, aldehyde, etc.) which make it a good candidate to show surface modifying properties if its water soluble components are properly extracted from it and used afterwards as an adsorptive type bio-based inhibitor.

The typical functional /active/ groups and the corresponding IR signals are also summed up in Table 1.

The above presented FTIR data have confirmed our supposition that the extract of orange peel should be an effective green inhibitor to be used in steel reinforced concrete structures.

A somewhat similar approach was considered and taken by Zapata, Balmaseda, Fregoso-Israel and Torres-García [20] when they studied the chemical structure of orange peel by FTIR technique as shown in Fig.3. Where we found most of the groups that appeared in our examination are similar to the groups that appeared in their analysis, for example, in the high energy region at $(3280.93) \mathrm{cm}^{-1}$ is due to a large amount of $\mathrm{OH}$ groups of the carbohydrates and those of lignin. Also at (1045) $\mathrm{cm}^{-1}$ corresponds to the link $\mathrm{C}-\mathrm{O}-\mathrm{H}$ or $\mathrm{C}-\mathrm{O}-\mathrm{R}$ (alcohols or esters) while the distinctive band at $(2925) \mathrm{cm}^{-1}$ is related to the presence of $\mathrm{C}-\mathrm{H}$ stretching vibration together with bending vibrations around $(1428) \mathrm{cm}^{-1}$ of aliphatic chains $\left(-\mathrm{CH}_{2}-\right.$ and $-\mathrm{CH}-$ ) forming the basic structure of this lignocellulosic materials.

\begin{tabular}{cc} 
Active Group & Positive Number \\
$\mathrm{OH}$ & $(3280.93) \mathrm{cm}^{-1}$ \\
\hline $\mathrm{CH}$ & $(2920.79) \mathrm{cm}^{-1}$ \\
\hline $\mathrm{P}-\mathrm{H}$ & $(2349.26) \mathrm{cm}^{-1}$ \\
\hline $\mathrm{C}=\mathrm{O}$ & $(1739.69) \mathrm{cm}^{-1}$ \\
\hline $\mathrm{C}=\mathrm{C}$ & $(1606.04) \mathrm{cm}^{-1}$ \\
\hline$-\mathrm{CH}_{2}$ & $(1416.56) \mathrm{cm}^{-1}$ \\
\hline$-\mathrm{CH}_{3}$ & $(1367.84) \mathrm{cm}^{-1}$ \\
\hline $\mathrm{CH}-\mathrm{OH}$ & $(1236.60) \mathrm{cm}^{-1}$ \\
\hline $\mathrm{C}-\mathrm{O}-\mathrm{H}$ or C-O-R & $(1012.75) \mathrm{cm}^{-1}$ \\
\hline $\mathrm{CH}$ & $(670.85) \mathrm{cm}^{-1}$ \\
\hline $\mathrm{C}-\mathrm{Br}$ & $(664.41) \mathrm{cm}^{-1}$ \\
\hline $\mathrm{O}-\mathrm{N} \equiv \mathrm{O}$ & $(586.22) \mathrm{cm}^{-1}$ \\
\hline $\mathrm{S}-\mathrm{S}$ & $(533.05) \mathrm{cm}^{-1}$
\end{tabular}

Table 1. The IR active groups and positive numbers of the FTIR tested orange peel powder 1. táblázat A vizsgált narancshéj por mintában detektált IR aktív csoportok és a hozzájuk rendelt hullámszámok

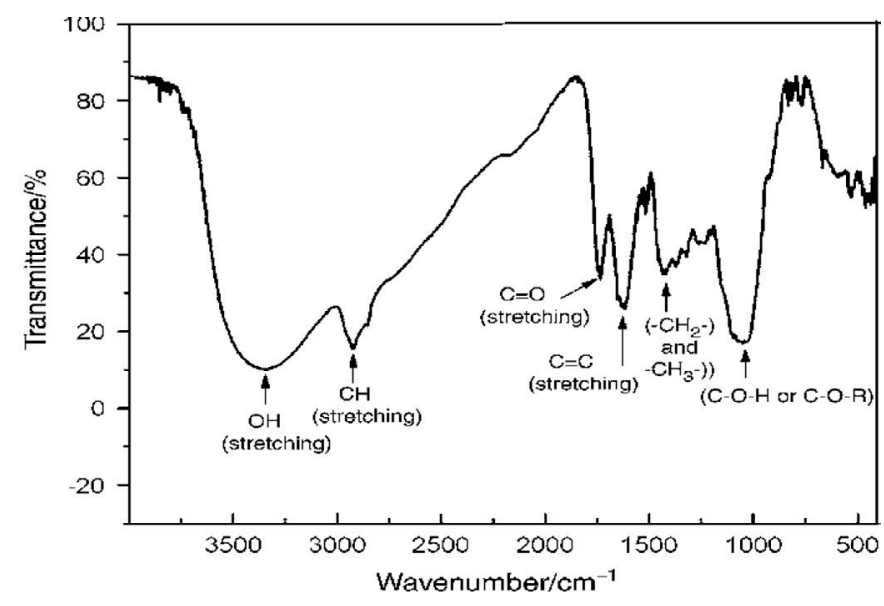

Fig. 3. FTIR spectrum of the dried orange peel sample [20]

3. ábra Szárított narancshéj minta [20] FTIR spektruma 


\begin{tabular}{|c|c|c|c|c|c|c|}
\hline Time & $\begin{array}{l}E(V) \text { for samples } \\
\text { in } \\
3.5 \% \mathrm{NaCl} \text { solution }\end{array}$ & $\begin{array}{l}\text { E (V) for samples in } \\
3.5 \% \mathrm{NaCl} \text { solution } \\
+ \text { green inhibitor }\end{array}$ & $\begin{array}{l}\mathrm{i}_{\text {corr }}\left(\mu \mathrm{A} / \mathrm{cm}^{2}\right) \text { for } \\
\text { samples in } \\
3.5 \% \mathrm{NaCl} \text { solution }\end{array}$ & $\begin{array}{c}\mathrm{i}_{\text {corr }} \\
\left(\mu \mathrm{A} / \mathrm{cm}^{2}\right) \text { for samples in } \\
3.5 \% \mathrm{NaCl} \text { solution }+ \\
\text { green inhibitor }\end{array}$ & $\begin{array}{c}\text { CR } \\
\text { (mm/year) } \\
\text { for samples in } \\
\text { 3.5\% } \mathrm{NaCl} \text { solution }\end{array}$ & $\begin{array}{c}\text { CR } \\
\text { (mm/year) } \\
\text { for samples in } \\
\text { 3.5\% } \mathrm{NaCl} \text { solution + } \\
\text { green inhibitor }\end{array}$ \\
\hline Oh & $-0,942$ & $-0,857$ & 3,116 & 2,681 & 0,0362 & 0,0312 \\
\hline $1 \mathrm{~h}$ & $-0,895$ & $-0,808$ & 2,588 & 2,511 & 0,0300 & 0,0292 \\
\hline $3 h$ & $-0,895$ & $-0,837$ & 2,542 & 2,371 & 0,0300 & 0,0276 \\
\hline $5 \mathrm{~h}$ & $-0,914$ & $-0,895$ & 2,572 & 2,411 & 0,0300 & 0,0280 \\
\hline $7 \mathrm{~h}$ & $-0,972$ & $-0,885$ & 2,429 & 2,402 & 0,0282 & 0,0279 \\
\hline $24 h$ & $-0,867$ & $-0,875$ & 2,572 & 2,208 & 0,0299 & 0,0257 \\
\hline
\end{tabular}

Table 2. Initial corrosion properties of the steel specimen measured in the first 24 hours 2. táblázat A vizsgált betonacél mintákon az elsö 24 órában mért korróziós jellemzők

\subsection{Corrosion Properties Obtained from Electrochemical Polarization Experiments}

The adsorptive properties of the chosen green inhibitor can be indirectly sized up relatively easily from the polarization curves which technique is widely used by electrochemists working in the field of corrosion studies. In our case a computer controlled (ZAHNER type potentiostat was used to record the current - potential data which were then converted to corrosion rates according to standard procedures described in ASTM STP 908 [21]. The so obtained corrosion properties $\left(E / \mathrm{V}, \mathrm{i}_{\text {corr }}\right.$, and CR values) are all summarised in Table 2 and the corrosion rates (CR) are depicted also in Fig. 4.

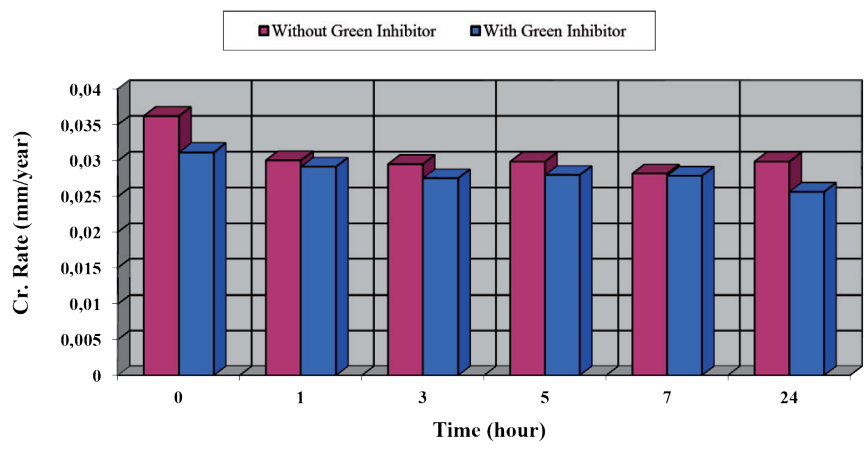

Fig. 4. Calculated initial corrosion rates of the given steel specimen being immersed in $3.5 \% \mathrm{NaCl}$ solution in contact with air in the first 24 hours

4. ábra Levegövel érintkezö és 3,5\% NaCl tartalmú vizes oldatban tesztelt acélminták számitott korróziósebesség adatai az első 24 órában

As it is seen in Figure 4, the tendency of the corrosion rates is diminishing with time of immersion during the tested first short period of 24 hours, and the rates are always somewhat lower in cases when the $\mathrm{NaCl}$ solution contained the extract of the orange peel inhibitor. As the start of chemical attack (i.e. initiation of surface rusting) on the surface of such freshly prepared (cleaned and mechanical polished) steel specimen is always rather slow in such neutral and stagnant aqueous salt solutions in contact with air, the observed tendency should be evaluated accordingly. It means that the inhibitive effect of the chosen and so tested green inhibitor is really plausible and promising.

\subsection{Results of SEM and EDS Analysis}

In addition to testing the initial corrosion behaviour of the given steel material by the above described electrochemical testing techniques, several sets of the steel rods of about $10 \mathrm{~cm}$ long (half having their as-received original surface condition and half acid pickled) were put and kept in three different $\mathrm{NaCl}$ solutions for 30 days. One set was the blank (without inhibitor) and the two other sets contained 1 or $3 \%$ inhibitors as well.

After 30 days the corroded samples surfaces were examined by scanning electron microscopy (SEM) and the scanned surface areas were also EDS analysed to detect the observable chemical elements in the close to surface zones in depth of about $1 \mu \mathrm{m}$.

The first SEM image (Fig. 5) shows the as-received surface condition of the reinforcing steel rebar sample obtained from a steel works (ÓAM Ltd., Ózd). Its oxide cover was identified as some kind of mill-scale with an average chemical composition close to that of $\mathrm{FeO}$ (wüstite). This surface product is due to the high temperature metal forming technology (hot rolling in air), and it seems to be well adhered, but shows several cracks and distorted areas at higher magnification (Fig. 5).

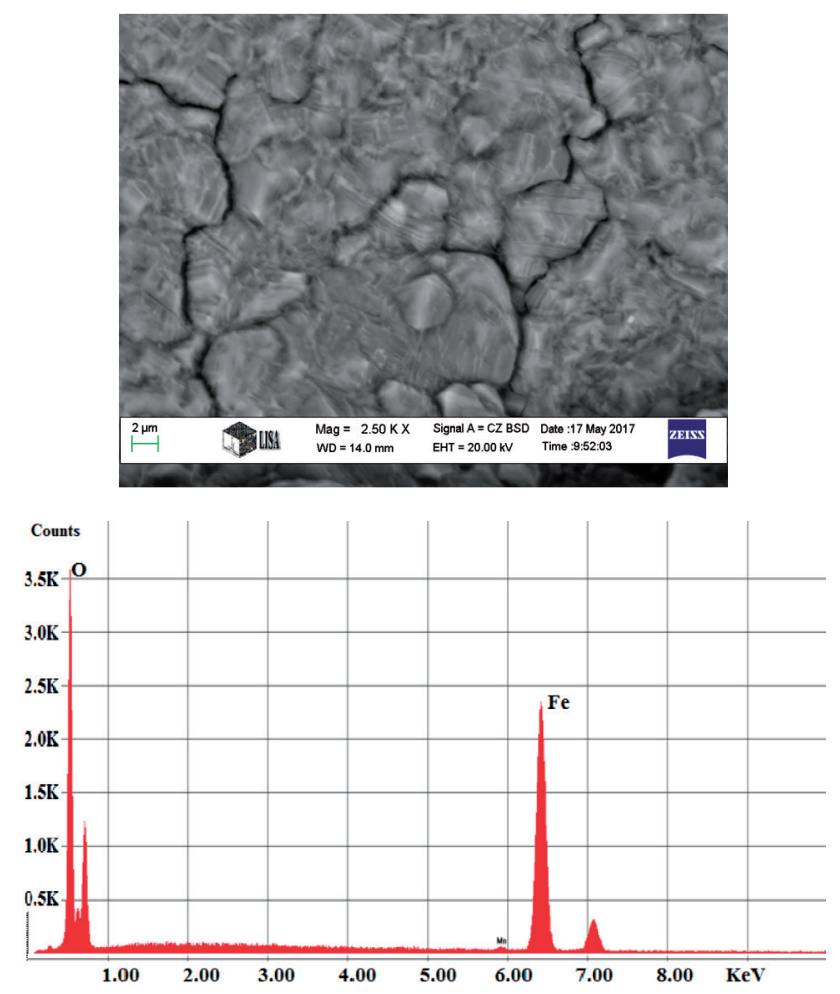

Fig. 5. SEM image and EDS analysis of the steel rebar as recieved from the steel mill 5. ábra Az acélgyártól kapott betonacél minta felületének elektronmikroszkópos (SEM) képe és kémiai elemi összetétele EDS (elektronmikroszondás) elemzéssel meghatározva 
After 30 days immersion in the testing $\mathrm{NaCl}$ solutions, the corroded surfaces of the steel rebar samples showed quite varied surface morphologies as it is demonstrated in a randomly selected SEM image shown in Figure 6.

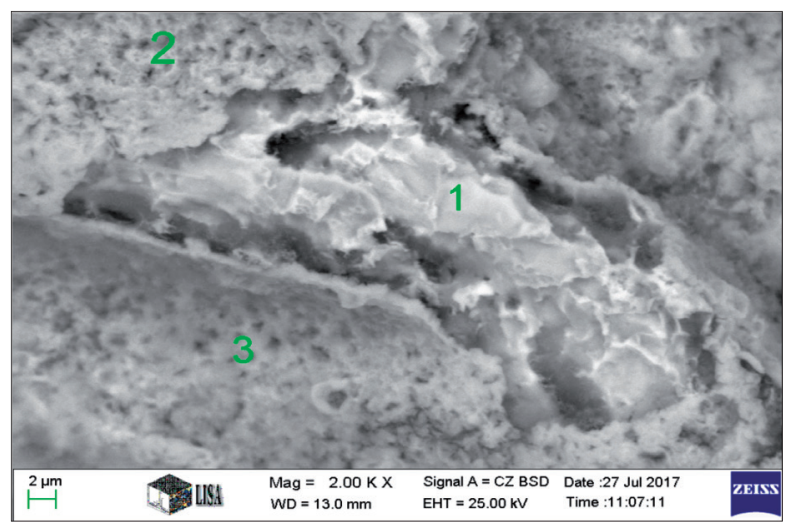

Fig. 6. SEM image of a small rusted surface region of a steel rebar sample first $\mathrm{HCl}$ acid pickled to remove the mill-scale then kept in $3.5 \% \mathrm{NaCl}$ solution with $3 \%$ inhibitor in air for one month. EDS spot analysis showed approximate $\mathrm{Fe}$ and $\mathrm{O}$ atomic percentages at Point 1: $\mathrm{Fe} \sim 89$ at\%, $\mathrm{O} \sim 9$ at\%; at Point 2: Fe $\sim 54$ at\%, $O \sim 44$ at\%; and at Point 3: Fe $\sim 49$ at \%, O 50 at \%

6. ábra Sósavas pácolással revétlenitett, majd egy hónapig 3,5\% NaCl-ot és 3\% inhibitort is tartalmazó, s levegôvel is érintkező vizes oldatban korrodálódott betonacél minta rozsdás felületének kicsiny részlete (SEM felvétel), és a jelölt három pontban elvégzett EDS mikroszondás elemzések eredménye (közelitö Fe és O atomszázalékos értékek): az 1 pontban: $\mathrm{Fe} \sim 89$ at\%, O 9 at\%; a 2 pontban: $\mathrm{Fe} \sim 54$ at\%, O 44 at\%; és a 3 pontban: $\mathrm{Fe} \sim 49$ at\%, O 50 at\%.

Although the exact identification of the most probable corrosion products was not aiming at in this research, but their approximate average surface coverage was estimated based on the EDS area analysis taking into consideration the limitations of this technique while trying to analyse such rather thin and heterogeneous surface layers of various and loose corrosion products. Therefore, for the correct interpretation of the EDS analysis one should always remember the important fact that the EDS microanalysis (using the given apparatus type ZEISS) provides information only from the outermost surface zone with a maximum depth of about $1 \mu \mathrm{m}$. Moreover, the elementary composition obtainable from such a close to surface volume does not contain the amount of hydrogen, which element is not detectable by this technique. Hence, the atomic percentages given below the SEM images (i.e. in Figures 6-7) do provide only some approximate average ratios of $\mathrm{Fe}$ and $\mathrm{O}$ present in the surface oxide-hydroxide layers plus that of mostly Fe in the zone (i.e. in the bulk steel) underneath the oxide-hydroxide cover.

Knowing that the oxide-hydroxide corrosion products formed in such circumstances on such type of steels are different iron oxide-hydroxides like Lepidocrocite $(\gamma-\mathrm{FeOOH})$, Akaganeit $(\beta-\mathrm{FeOOH})$, and Goethite $(\alpha-\mathrm{FeOOH})$, it follows that in all these phases the atomic ratios of $\mathrm{Fe}$ to $\mathrm{O}$ is 1:2 (i.e. $\sim 33$ at.\% to $\sim 66$ at.\%), disregarding the presence of $\mathrm{H}$. Based on such a comprehension, and evaluating the EDS detected Fe to $\mathrm{O}$ atomic percentages given in Figure 7, it can be concluded with high certainty, that the oxide-hydroxide corrosion layer formed on the surfaces of the steel rebar samples exposed for one month to the corrosion attack of inhibited stagnant $\mathrm{NaCl}$ aqueous test solutions in contact with air, could not develop/ grow as thick as in the case without inhibitor.
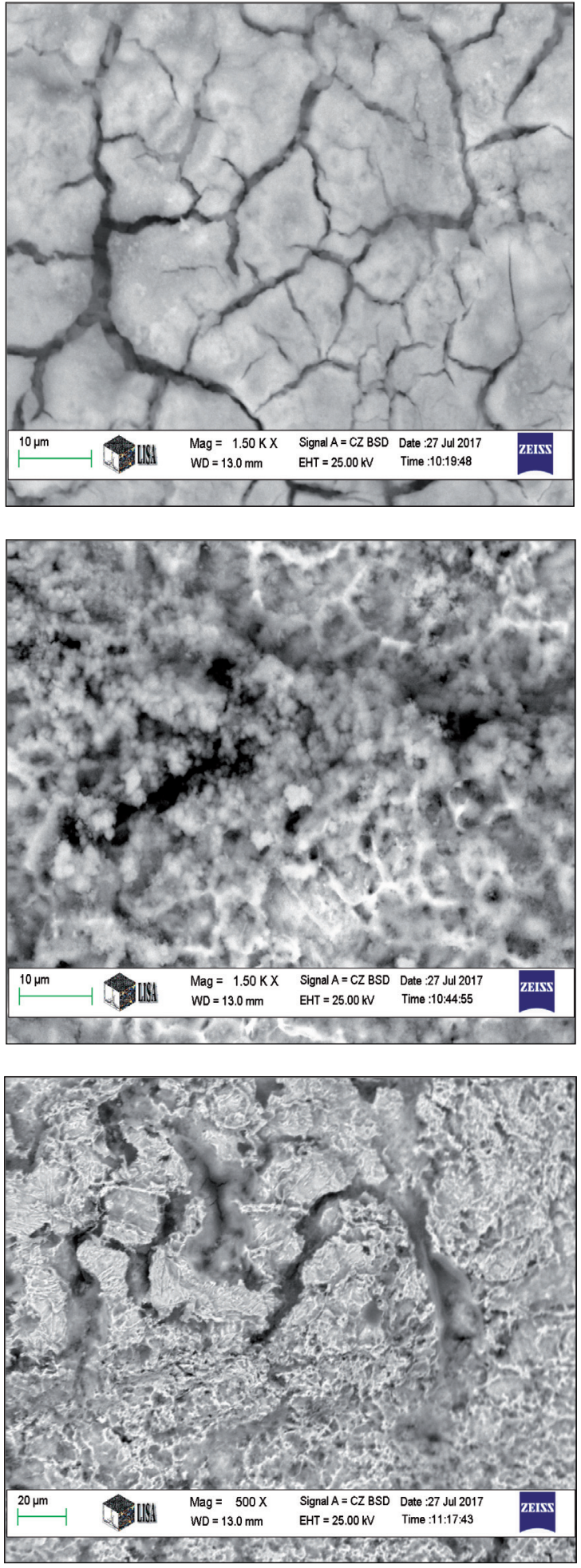

Fig. 7. SEM images with the results of EDS area analysis of the as received steel rebar samples kept in stagnant $\mathrm{NaCl}$ solutions without (a-), with $1 \%(b-)$, and $3 \%$ $(c-)$ inhibitor for one month. Approximate $F e$ and $O$ concentrations detected in the close to surface thin corroded zones were as follows: a) $\mathrm{Fe} \sim 52.6$ at.\%, $O \sim 44.3$ at.\%; b) $\mathrm{Fe} \sim 61.2$ at.\%, O 35.7 at.\%; and c) $\mathrm{Fe} \sim 66$ at.\%, O 18 at.\%. (Other minor detected elements are not listed.)

7. ábra Egy hónapig stagnáló (nem kevert) $\mathrm{NaCl}$-os vizes oldatban egy hónapig korrodálódott betonacél minták felületének SEM felvételei és ezeken a korrodálódott felületrészeken EDS mikroszondás elemzéssel meghatározott Fe és O atomszázalékos koncentrációk (a kis mennyiségben detektált egyéb elemek nélkül). Jelölések: ( $a-$ ) inhibitor nélkül; (b-) 1\% inhibitorral; és (c-) 3\% inhibitorral. Fe és O tartalmak a vizsgált minták felületközeli tartományaiban: a) $\mathrm{Fe} \sim 52.6$ at.\%, O 44.3 at.\%; b) $\mathrm{Fe} \sim 61.2$ at.\%, O 35.7 at.\%; and c) $\mathrm{Fe} \sim 66$ at.\%, O 18 at.\%. 


\section{Concluding remarks}

During our laboratory experiments the tested orange peel extract has shown promising positive effect on inhibiting the corrosion rate of iron in close to neutral aqueous $\mathrm{NaCl}$ solutions in contact with air.

In the future the new orange peel extract inhibitor will also be tested as an admixture of freshly prepared concrete laboratory specimens reinforced with steel rebars in order to explore its potential applicability in the building industry.

\section{Acknowledgements}

We would like to thank everyone who helped us to complete this research; especially Árpád Kovács working in the SEM laboratory at the Institute of Physical Metallurgy, Metal Forming and Nanotechnology, and the technician from the BorsodChem extraction laboratory.

We must also not forget the efforts of the Institute of Metallurgy in providing all the possibilities available to us in order to make this research successful.

\section{References}

[1] Abosrra, L. - Ashour, A. F. - Youseffi, M. (2011): Corrosion of Steel Reinforcement in Concrete of Different Compressive Strengths, Journal of Construction and Building Materials, Vol.25, No.10, pp. 3915-3925. https://doi.org/10.1016/j.conbuildmat.2011.04.023

[2] Talbot, D. - Talbot, J. (1998): Corrosion Science and Technology, CRC Press, Taylor \& Francis, ISBN 9781138745896.

[3] Bentur, A. - Diamond, S. - Berke, N. S.(1997): Steel Corrosion in Concrete: Fundamentals and Civil Engineering Practice, CRC Press, Taylor \& Francis, ISBN 9780419225300.

[4] Bertolini, L. - Elsener, B. - Pedeferri, P. - Redaelli, E. - Polder, R.B. (2014): Corrosion of Steel in Concrete: Prevention, Diagnosis, Repair, 2nd Edition, Wiley, ISBN: 978-3-527-33146-8.

[5] ACI Committee 222 (2005): Protection of Metals in Concrete Against Corrosion, ACI 222R-01, ACI Manual of Concrete Practice.

[6] Broomfield, J. P. (2007): Corrosion of Steel in Concrete: Understanding Investigation and Repair, Second Edition, CRC Press, Taylor \& Francis, London, ISBN 9780415334044.

[7] Wong, H. S. - Karimi, A. R. - Buenfeld, N. R. - Zhao, Y. X. - Jin, W. L. Microstructure of corroded steel-concrete interface, on the web: http://www.imperial.ac.uk/structural-engineering/research/structural-materials/microstructure/

[8] Zhao, Y. X. - Karimi, A. R. - Wong, H. S. - Hu, B. Y. - Buenfeld, N. R. Jin, W. L. (2011): Comparison of Uniform and Non-uniform Corrosion Induced Damage in Reinforced Concrete Based on a Gaussian Description of the Corrosion Layer, Corrosion Science, Vol.53, No.9, pp.2803-2814. https://doi.org/10.1016/j.corsci.2011.05.017

[9] Sagoe-Crentsil, K. K. - Glasser, F. P. (1989): Steel in Concrete: Part I. A Review of the Electrochemical and Thermodynamic Aspects, Magazine of Concrete Research, Vol.41, No.149, pp.205- 212. https://doi.org/10.1680/macr.1989.41.149.205

[10] Glasser, F. P. - Sagoe-Crentsil, K. K. (1989): Steel in Concrete: Part II. Electron Microscopy Analysis, Magazine of Concrete Research, Vol.41, No.149, pp.213-220. https://doi.org/10.1680/macr.1989.41.149.213

[11] Sagoe-Crentsil, K. K. - Glasser, F. P. (1993): Green Rust, Iron Solubility and the Role of Chloride in the Corrosion of Steel at High pH, Cement and Concrete Research, Vol.23, No.4, pp.785-791. DOI: 10.1016/0008 8846(93)90032-5

[12] Burubai, W. - Dagogo, G.(2007): Comparative Study of Inhibitors on the Corrosion of Mild Steel Reinforcement in Concrete, Agricultural Engineering International: the CIGR Ejournal, Vol.9, pp.1-10.
[13] Mahdi, A. S.(2014): Urea Fertilizer as Corrosion Inhibitor for Reinforced Steel in Simulated Chloride Contaminated Concrete Pore Solution, International Journal of Advanced Research in Engineering and Technology, Vol.5, No.5, pp.30-39.

[14] Al-Otaibi, M. S. - Al-Mayouf, A. M. - Khan, M. - Mousa, A. A. - AlMazroa, S. A. - Alkhathlan, H. Z.(2014): Corrosion Inhibitory Action of Some Plant Extracts on the Corrosion of Mild Steel in Acidic Media, Arabian Journal of Chemistry, Vol.7, No.3, pp.340-346. https://doi.org/10.1016/j.arabjc.2012.01.015

[15] Sanyal, B. (1981): Organic Compounds as Corrosion Inhibitors in Different Environments - A review, Progress in Organic Coatings, Vol.9, No.2, pp.165-236. https://doi.org/10.1016/0033-0655(81)80009-X

[16] Sangeetha, M. - Rajendran, S. - Muthumegala, T. S. - Krishnaveni, A. (2011): Green Corrosion inhibitors-An Overview, Zaštita Materijala, Vol.52, No.1, pp.3-19. http://www.sitzam.org.rs/zm/2011/No1/ZM_52_1_3.pdf

[17] Kundu, M. - Prasad, S. K. - Kumar, V. (2016): A Review Article on Green Inhibitors of Reinforcement Concrete Corrosion, International Journal of Emerging Research in Management \&Technology, Vol.5, No.1, pp.42-46. https://www.ermt.net/docs/papers/Volume_5/1_January2016/V5N1-125.pdf

[18] EN 10080 (2005): Steel for the Reinforcement of Concrete, European Commission mandate, 23 December 2005.

[19] Sastri, V. S.(2011): Green Corrosion Inhibitors: Theory and Practice, John Wiley \& Sons, Inc, ISBN: 978-0-470-45210-3.

[20] Zapata, B. - Balmaseda, J. - Fregoso-Israel, E. - Torres-García, E. (2009): Thermo-kinetics study of orange peel in air, Journal of Thermal Analysis and Calorimetry, Vol.98, pp.309-315. https://doi.org/10.1007/s10973-009-0146-9

[21] Moran, G. C. - Labine, P. (1984): ASTM STP 908: Corrosion Monitoring in Industrial Plants Using Nondestructive Testing and Electrochemical Methods, Canada, 22-24 May 1984, ISBN-EB: 978-0-8031-4974-8.

Ref.:

Abdulsada, Shaymaa Abbas - Török, Tamás I. - Fazakas, Éva: Preliminary Corrosion Testing of Steel Rebar Samples in 3.5\% NaCl Solution with and without a Green Inhibitor Építőanyag - Journal of Silicate Based and Composite Materials, Vol. 70, No. 2 (2018), 48-53. p https://doi.org/10.14382/epitoanyag-jsbcm.2018.10

Acélbetétek korróziós vizsgálata 3,5\% $\mathrm{NaCl}$ oldatban zöld inhibitor alkalmazásával és anélkül

Olcsó szerves hulladéknak minôsülő narancshéjból új inhibitor anyagot (ún. „zöld” inhibitort) vontunk ki, melynek acélbetétek korrózióvédelmi célra történô alkalmazhatóságát többféle kísérleti módszerrel laboratóriumi körülmények között vizsgáltuk. Az egyik magyarországi acélgyártól kapott betonacél minták több sorozatát (eredeti revés és revétlenített állapotukban egyaránt) vizes 3,5 \%-os nátriumklorid oldatokba merítettük és a szokásos elektrokémiai polarizációs méréstechnikát alkalmazva meghatároztuk a metanolos extrakcióval kinyert inhibitort is esetenként (1, illetve $3 \%$-ban) tartalmazó vizes közegben kialakuló kezdeti korróziós sebességeket az elsô 24 órában. Az új „zöld" inhibitor aktív csoportjait FTIR spektrometriásan identifikáltuk, mely aktív csoportoknak köszönhetôen ezen új inhibitor felületszorpciós hatása által képes volt jól érzékelhetôen csökkenteni a vizsgált acél minták korróziósebességét. Az egy hónapos korróziós hatásnak kitett mintákat pásztázó elektronmikroszkópos (SEM) és EDS mikroszondás felületanalitikai módszerekkel is elemeztük. Kulcsszavak: acélbetét vasbetonhoz, narancshéj, korróziós tulajdonságok, SEM EDS elemzés 